\title{
MONITORING THE CAPACITOR CHARGE VOLTAGE IN THE PULSE VOLTAGE GENERATOR USING THE ACCELERATOR OF RELATIVISTIC ELECTRON BEAMS
}

\author{
A.B. Batrakov, E. G. Glushko, A.A. Zinchenko, Y.F. Lonin, A.G. Ponomarev, S.I. Fedotov \\ National Science Center "Kharkov Institute of Physics and Technology", Kharkiv, Ukraine \\ E-mail: batrakov@kipt.kharkov.ua
}

Noise-protected high charge voltage meter was manufactured using terminal capacitors of the four-channel pulse voltage generator (PVG). The noise protection is provided by the use of communication lines with fiberoptic cables. This measuring device is successfully used for the relativistic electron beam (REB) accelerator "Temp-B" and it provides the measurement accuracy of $\sim 0.5 \%$ in the electromagnetic noise environment.

PACS: 29.20.-c; 29.90. +r

\section{INTRODUCTION}

The available method of charging the high-voltage capacitors of pulse voltage generators monitoring the input charge voltage fails to provide reliable PVG chargerelated information due to voltage losses at accelerator structure elements. The operation of "Temp-B" accelerator showed the need for the control of the charge voltage of capacitors used by PVGs. The voltage control at the terminal capacitors of four-channel PVG allows us to monitor the charging process and obtain identical charge voltage for each PVG channel.

\section{VOLTAGE MEASUREMENT DESCRIPTION}

Experimental investigations of the parameters of hard braking X-ray radiation using "Temp-B" accelerator as a reactor zone simulation device require controlling a high charge direct voltage of PVG capacitors. These modes of operation of the "Temp-B" accelerator require the generation of high-current beams with the current of tens of $\mathrm{kA}$ and the particle energy of $\sim \mathrm{MeV}$ [1]. Such parameters can be obtained using the fourchannel PVG. The PVG stored energy for the charge voltage of $100 \mathrm{kV}$ was $150 \mathrm{~kJ}$. PVG channels were commutated using three-electrode dischargers filled with nitrogen under the pressure of $5 \cdot 10^{5} \mathrm{~Pa}$. These dischargers have the best indices as for the scattering value and the actuation time in comparison with other structures. The casings of dischargers were made of caprolon. Using hermetically sealed flange connections the dischargers were assembled in series forming the monoblock with the optical connection of discharge gaps to improve the mutual irradiation triggering. Each channel includes 19 high-voltage capacitors, charging resistances and appropriate dischargers. The charging resistances were made of the sections of vinyl tubes filled with the $\mathrm{NaCl}$ water solution. Fig. 1 shows the external view of PVG.

During the capacitor charging the inconsistency of the values of charge resistances was revealed due to the change in the temperature and chemical purity of the solution. It results in different charge time of PVG channels. The measuring of the charge voltage of terminal capacitors of each channel allows us to control the charge process. A high direct voltage is usually measured using the high-ohmic divider that was designed to meet the requirements set to high-voltage equipment.

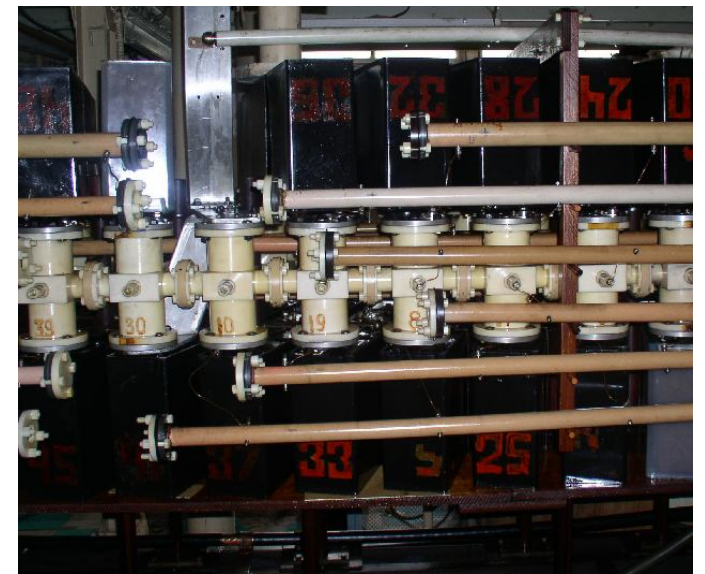

Fig. 1. Pulse voltage generator

The operation of "Temp-B" accelerator is related to the availability of high quick-changing currents and high voltage surges. It results in the formation of electromagnetic fields near the test rig and these fields can create interferences in measurement devices that considerably exceed the measured signal [2]. Therefore, the measuring devices are placed at a certain distance from the accelerator and are kept inside the screening casings. Availability of large alternate magnetic fields creates a big problem for communication lines consisting of screened coaxial cables due to the "earthing loops". A change in the magnetic field can induce high voltages in such loops. The use of optic cable as a communication line allows us to considerably improve noise-protection and safety of the personnel working in the high-voltage environment.

Fig. 2 gives the block-diagram of the device designed for the PVG charge voltage control.

The measurement control diagram is as follows. The modules $1-1 \ldots 1-4$ are the relaxation generators of the converters of capacitor charge voltage into the succession of light pulses whose recurrence frequency is in proportion to this voltage. Then, the signals are transmitted through the fiberoptic linear cable 2-1...2-4 to the converting receivers of light pulses 3-1...3-4 and are converted into the electric signal compatible with the receiver input of the digital data transfer system 4 (DDTS). In is intended for the conversion of parallel data formats into the sequential data format, their transfer via the fiberoptic cable and the conversion of the sequential data format back to the parallel one. The information recording mode is realized via 19 inputs with 
the time period of $5 \mu \mathrm{s}$. In the transmitting part of DDTS the digital data succession with varying frequency is transmitted through the fiberoptic cable 5 to the receiving part of the digital data transfer system 6 . Then, the information is transmitted to the voltage indicators $7-1 \ldots 7-4$.

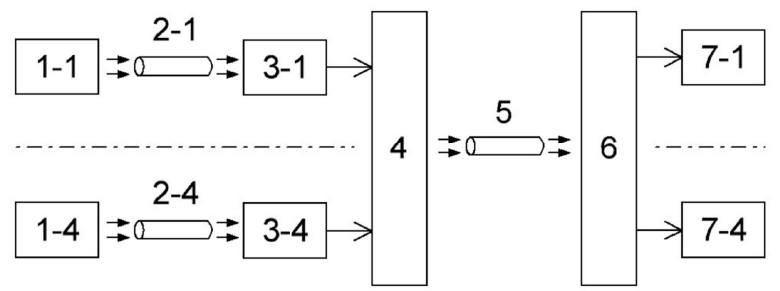

Fig. 2. Block diagram of the device designed for the PVG charge voltage control: 1-1...1-4 capacitor charge voltage-to-frequency converters; 2-1 ...2-4 optic cables of 6 m long; 3-1...3-4 - receiving converters of light pulses; 4 -transmission part of the digital data transfer system; 5 -optical cable of $100 \mathrm{~m}$ long; 6 - receiving part of the digital data transfer system; 7-1 ...7-4 - voltage indicators

Fig. 3 shows the high voltage meter diagram.

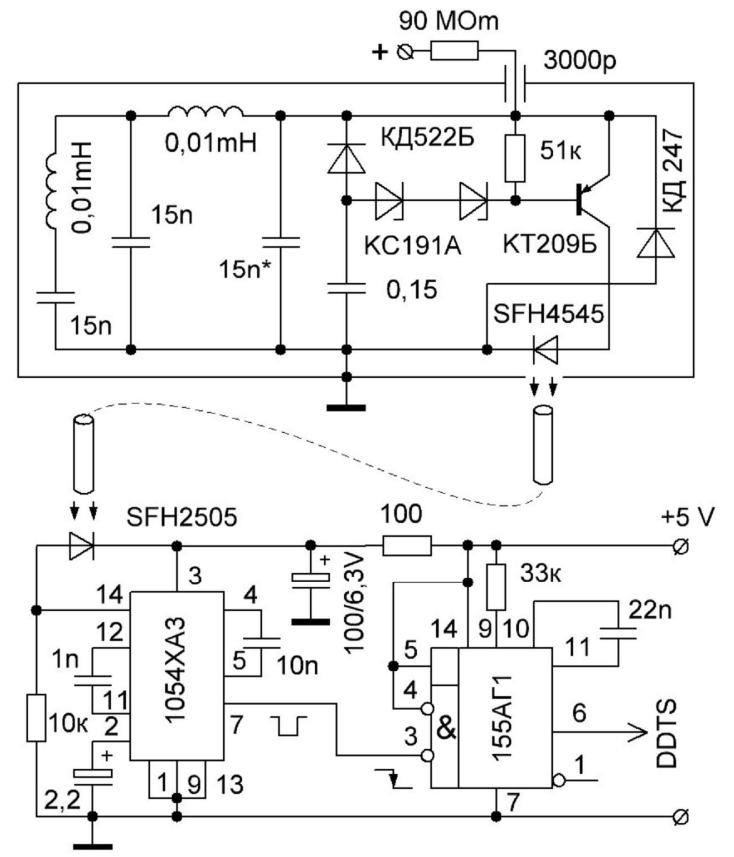

Fig. 3. High voltage meter diagram

High voltage meter is based on the relaxation transistor-type generator [3] that enables easy voltage-topulse recurrence frequency transformation. This circuit allows for the accurate conversion of the order of tenth percent fractions. A stable operation of the circuit is achieved due to the automatic stabilization of the difference of threshold voltages [4].

To generate the rectangular current pulse passing through the light diode we use the storage LC-line that allows us to obtain current pulses of $\sim 500 \mathrm{MA}$ with the duration of $\sim 3 \mu \mathrm{s}$ [5].

The light signal receiver was made using photodiode and special-purpose microcircuit 1054 XA3 that shapes a standard rectangular pulse. Fig. 4 gives the output pulse oscillogram. This pulse is transmitted to the receiver input of the digital data transfer system. This circuit allows us to measure capacitor voltages up to $90 \mathrm{kV}$. The voltage-to-pulse recurrence frequency conversion accuracy was of $\sim 0.5 \%$.

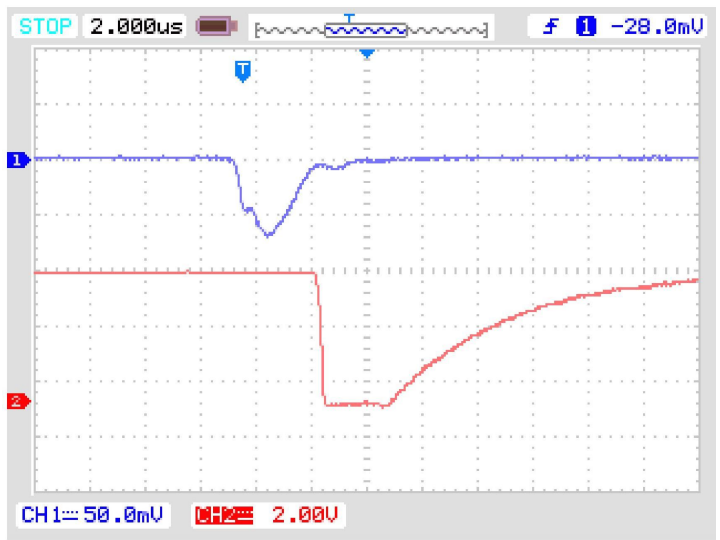

Fig. 4. Oscillogram of signal transmitter and light pulse receiver. Beam 1 - the current passing through the light

diode; Beam 2 -output pulse after the converting receiver of light pulses

A charge voltage value of the capacitors of pulse voltage generator is defined by the frequency of transmitted pulses. The frequency in the range of $170 \mathrm{~Hz}$ to $1.7 \mathrm{kHz}$ corresponds to the capacitor voltage of 9 to $90 \mathrm{kV}$.

\section{CONCLUSIONS}

1. A high voltage meter was developed to measure the charge voltage of PVG capacitors using the microsecond accelerator "Temp-B" that allows us to control the capacitor charge voltage in each PVG channel. The measurement error is within $\sim 0.5 \%$.

2. The signal transmission device circuit was developed to transmit the signal through the digital line with the varying pulse recurrence frequency.

3. The developed technique allows for the control of the charge of PVG capacitors at a distance of $100 \mathrm{~m}$ from the object.

\section{REFERENCES}

1. A.B. Batrakov, S.P. Bondarenko, A.G. Lonin, A.G. Ponomarev, G.V. Sotnikov. Optimizing the parameters of Relativistic Electron Beams to Generate Intense Slowing-down R-Radiation // Problems of Atomic Science and Technology. Series "Plasma Electronics and New Methods of Acceleration". 2010, № 4, p. 21-24.

2. A.B. Batrakov, E.G. Glushko, E.G. Yegorov, A.A. Zinchenko, Y.F. Lonin, A.G. Ponomarev, S.I. Fedotov. Diagnostic module for the radiation beam system "Temp" // Problems of Atomic Science and Technology. Series "Plasma Physics". 2017, № 1, p. 112-114.

3. V.P. Diakonov. Avalanche Transistors and the Use of Them for Pulse Devices. M.: "Sov. Radio", 1973.

4. E.P. Bochkar, A.I. Zakharov, A.P. Sokolov // PTE. 1986, № 1, p. 204.

5. G.A. Mesiats. Generation of High-Power Nanosecond Pulses. M.: "Sov. Radio", 1974.

Article received 25.01.2020 


\section{КОНТРОЛЬ НАПРЯЖЕНИЯ ЗАРЯДА КОНДЕНСАТОРОВ В ГЕНЕРАТОРЕ ИМПУЛЬСНОГО НАПРЯЖЕНИЯ НА УСКОРИТЕЛЕ РЭП}

А.Б. Батраков, Е.Г. Глуико, А.А. Зинченко, Ю.Ф. Лонин, А.Г. Пономарев, С.И. Федотов

Изготовлен помехозащищенный измеритель высокого зарядного напряжения на оконечных конденсаторах четырехканального генератора импульсного напряжения (ГИН). Помехозащищённость обеспечивается применением линий связи с использованием оптоволоконного кабеля. Данный измеритель успешно применяется на ускорителе РЭП «Темп-Б» и обеспечивает точность измерения $\sim 0,5 \%$ в условиях сильных электромагнитных помех.

\section{КОНТРОЛЬ НАПРУГИ ЗАРЯДУ КОНДЕНСАТОРІВ У ГЕНЕРАТОРІ ІМПУЛЬСНОЇ НАПРУГИ НА ПРИСКОРЮВАЧІ РЕП}

\section{О.Б. Батраков, С.Г. Глушко, А.О. Зінченко, Ю.Ф. Лонін, О.Г. Пономарьов, С.І. Федотов}

Виготовлений перешкодозахищений вимірювач високої зарядної напруги на кінцевих конденсаторах чотириканального генератора імпульсної напруги (ГІН). Перешкодозахищеність забезпечується застосуванням ліній зв'язку з використанням оптоволоконного кабеля. Даний вимірювач успішно використовується на прискорювачі РЕП «Темп-Б» і забезпечує точність вимірювання $\sim 0,5 \%$ в умовах сильних електромагнітних перешкод. 